\title{
Long-term effectiveness and safety of infliximab, golimumab and golimumab-IV in rheumatoid arthritis patients from a Canadian prospective observational registry
}

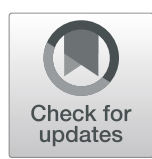

Proton Rahman ${ }^{1}$, Philip Baer², Ed Keystone ${ }^{3}$, Denis Choquette ${ }^{4}$, Carter Thorne ${ }^{5}$, Boulos Haraoui ${ }^{4}$, Andrew Chow ${ }^{6}$, Rafat Faraawi ${ }^{7}$, Wojciech Olszynski ${ }^{8}$, John Kelsall ${ }^{9}$, Emmanouil Rampakakis ${ }^{10}$, Allen J. Lehman ${ }^{11}$ and Francois Nantel ${ }^{11^{*}}$ (D)

\begin{abstract}
Background: Long-term clinical registries are essential tools to evaluate new therapies in a patient population that differs from those in randomized clinical trials. The objectives are to describe the profile of rheumatoid arthritis (RA) patients treated with anti-TNF agents in Canadian routine care.

Methods: RA patients eligible for treatment with Infliximab (IFX), golimumab (GLM) or intravenous golimumab (GLMIV) as per their respective Canadian product monographs were enrolled into the BioTRAC registry between 2002 and 2017. Study visits occurred at baseline and every 6 months thereafter. Effectiveness was assessed by changes in disease activity. Safety was evaluated by the incidence of adverse events (AEs) and drug survival.

Results: Of the 890 IFX-, 530 GLM- and 157 GLM-IV-treated patients, the proportion of females ranged from 77.0$86.6 \%$, the mean ages from $55.8-57.7$ and the mean disease duration from 6.5-8.6 years. A significant decrease in baseline disease duration and disease activity parameters (DAS, TJC, SJC, HAQ, AM stiffness, MDGA, PtGA, CRP, ESR) was observed over time. Treatment with IFX, GLM- and GLM-IV significantly improved all disease parameters over time. The incidence of AEs was 105, 113 and 82.6/100 PYs and the incidence of SAEs was 11.7, 11.2 and 4.68/100 PYs for IFX, GLM- and GLM-IV-treated patients, respectively.

Conclusion: Differences in baseline characteristics between patients treated with an anti-TNFs over time shows the evolution of treatment modalities over time. All treatments significantly reduced disease activity and improved functionality in a similar fashion. The incidence of adverse events was consistent with the safety profiles of IFX and GLM.
\end{abstract}

Trial registration: ClinicalTrials.gov Identifier: NCT00741793 (Retrospectively registered on August 26, 2008).

Keywords: Rheumatoid arthritis, Registry, Infliximab, Golimumab, Effectiveness, Safety

\footnotetext{
* Correspondence: fnantel@its.jnj.com

${ }^{11}$ Janssen Inc., 19 Green Belt Dr., Toronto, ON M3C 1N9, Canada

Full list of author information is available at the end of the article
}

(C) The Author(s). 2020 Open Access This article is licensed under a Creative Commons Attribution 4.0 International License, which permits use, sharing, adaptation, distribution and reproduction in any medium or format, as long as you give appropriate credit to the original author(s) and the source, provide a link to the Creative Commons licence, and indicate if changes were made. The images or other third party material in this article are included in the article's Creative Commons licence, unless indicated otherwise in a credit line to the material. If material is not included in the article's Creative Commons licence and your intended use is not permitted by statutory regulation or exceeds the permitted use, you will need to obtain permission directly from the copyright holder. To view a copy of this licence, visit http://creativecommons.org/licenses/by/4.0/. The Creative Commons Public Domain Dedication waiver (http://creativecommons.org/publicdomain/zero/1.0/) applies to the data made available in this article, unless otherwise stated in a credit line to the data. 


\section{Background}

Rheumatoid arthritis (RA) is a chronic, systemic inflammatory disease characterized by a symmetric, progressive inflammatory synovitis of the joints, leading to radiographic erosion, pain, functional disability, reduced quality of life and increased mortality [1]. Based on National and International treatment guidelines [2, 3], short-term glucocorticoids are recommended alongside disease-modifying antirheumatic drugs (DMARDs), specifically methotrexate (MTX), while biologic DMARDs (bDMARDs) are recommended after 3 months of failed treatment with at least 2 conventional DMARDs $[2,3]$. Since the approval of the first bDMARDs, the anti-TNF agents infliximab (IFX) and etanercept, several new agents and strategies have been introduced for the treatment of moderate to severe RA [3].

These guidelines predominantly use data from randomized clinical trials (RCTs) which, although designed to minimize potential biases, are carried out in selected populations which usually differ from patients treated in a real-world setting [4]. RCTs typically involve a small number of patients and represent only a limited spectrum of the patients seen in real-life clinical practice. In addition, the time of exposure to the drugs and controls is usually limited. Therefore, RCTs cannot answer important questions concerning long term safety or therapeutic strategy, and data from RCTs cannot easily be extrapolated to daily practice [5]. Despite their methodological limitations, observational studies allow the investigation of the long-term effectiveness and safety of new therapies and/or treatment strategies in a larger, more representative populations.

Here, we report long-term data on the profile of RA patients treated with several anti-TNF bDMARDs in Canadian routine clinical care over time, as well as describe their real-world effectiveness and safety over a 16calendar year period.

\section{Methods}

\section{Study design}

The Biologic Treatment Registry Across Canada (BioTRAC; NCT00741793) was a prospective, multi-center, industry-funded study that collected real-world clinical, laboratory, safety, and patient-reported data among ankylosing spondylitis, psoriatic arthritis, and RA patients treated with IFX, golimumab (GLM), intravenous golimumab (GLM-IV) or ustekinumab during routine care in academic and community centers in Canada between 2002 and 2018. BioTRAC was originally designed and launched in February 2002 as an effectiveness and safety registry for RA patients treated with IFX. Patients or the public were not involved in the design, or conduct, or reporting, or dissemination of this study. The registry was amended in 2005 to include IFX-treated patients with ankylosing spondylitis, and further expanded in
2006 to psoriatic arthritis. In 2010, patients treated with GLM were included. Finally, the registry was amended once more in 2014 to include RA patients treated with GLM-IV and psoriatic arthritis patients treated with UST. Additional details on the study design and an interim analysis of the IFX RA cohort have been previously published [6]. Prior to enrollment, patients were required to provide written informed consent to participate. Ethics approval was obtained from a central Research Ethics Board (IRB Service, Ontario, Canada) for private practices, and from respective Research Ethics Boards for institutional sites. The study was conducted in accordance with the Declaration of Helsinki and adheres to CONSORT guidelines. Data from this study were presented at the Canadian Rheumatology Association [7], PANLAR [8] and EULAR [9] 2019 conferences.

\section{Patient population}

Rheumatology patients, either bio-naive (2002-2006) or with $\leq 1$ prior biologic agent exposure (2006-2018), were enrolled and followed for up to 14 years with a study visit at baseline and every 6 months thereafter (a 2month visit was also included from 2002 to 2006). From 2006 to 2009, additional inclusion criteria included SJC $>10$ or $\mathrm{CRP}>0.8 \mathrm{mg} / \mathrm{dL}$ or $\mathrm{ESR}>30 \mathrm{~mm} / \mathrm{hr}$.

Patients treated with IFX were enrolled until May 2015 when the pre-specified recruitment number of $1500 /$ drug across diseases was met and were followed until Jan 2017. Enrolment for GLM- and GLM-IVtreated patients was stopped in Jun 2017 when the overall recruitment number of 3000 was met, and they were followed until Jun 2018. For the purposes of this analysis, patients with RA who initiated IFX, GLM or GLMIV treatment were included. All analyses were conducted in the full analysis set comprising patients receiving treatment without major eligibility violations.

\section{Data collection}

The following clinical, laboratory and patient-reported outcomes (PROs) were collected as per routine care at baseline and every 6 months thereafter: tender joint count based on 28 joints (TJC28), swollen joint count based on 28 joints (SJC28), Disease Activity Score 28 (DAS28), Health Assessment Questionnaire Disease Index (HAQ-DI), patient (PtGA) and physician (MDGA) global assessment of disease activity, C-reactive protein (CRP), erythrocyte sedimentation rate (ESR), morning (AM) stiffness, and pain. Target-specific outcomes, specifically SDAI remission $(\leq 3.3)$ and low disease activity (LDA; $\leq 11$ ) were calculated from raw scores. Safety was assessed with the incidence of treatment-emergent adverse events (AEs). As of 2014, due to changes in regulatory requirements, discontinuation due to unusual 
failure of efficacy (attributed to the product itself) started being reported as an $\mathrm{AE}$ of special interest.

\section{Statistical analysis}

The current study includes data from two distinct statistical analysis plans. The first plan covered the IFX cohort and was filed in May 2018. The second plan covered the remainder of cohort and included patients treated with either GLM or GLM-IV. Since the investigators had already been exposed to the IFX data, a decision was made not to do any statistical analysis comparing the IFX cohort to the other patients. Nonetheless, comparative data is presented therein as it provides an interesting vision of how patients evolved over the years and how each drug was used. To that effect, a stratified analysis of patient baseline profiles was conducted based on enrolment period, specifically 2002-2004, 2005-2008, 2009-2012, 2013-2015 and 2016-2017.

All outcomes were assessed descriptively using the median and/or mean and standard deviation (SD), 95\% confidence intervals (CI) of the mean for continuous variables, and frequency distributions for categorical variables. Variations in patient demographics and baseline characteristics across enrolment periods were assessed using the Wilcoxon Mann Whitney test for continuous variables and the Chi-square or Fisher's exact test for categorical variables.

Kaplan-Meier survival analysis was used to assess time to discontinuation. AEs were coded using the Medical Dictionary for Regulatory Activities (MedDRA version 20.0), and the proportion of patients who experienced an $\mathrm{AE}$ along with incidence rates were summarized by preferred term (PT). Statistical analyses were conducted with SPSS 24.0 (SPSS Inc., Chicago, IL) and SAS 9.4 (SAS Institute, Cary, NC, USA).

\section{Results}

Patient demographics and baseline characteristics are presented in Table 1. Of the 890 IFX-, 530 GLM- and 157 GLM-IV-treated patients, the proportion of females ranged from $77.0-86.6 \%$, the mean age from $55.8-57.7$ years and the mean disease duration from 6.5-9.8 years. Most patients were bio-naive. Patients treated with IFX received a mean (SD) dose of $3.4(0.57) \mathrm{mg} / \mathrm{Kg}$, over a median (min-max) of 13 (1-114) infusions representing a total exposure of 2714 patient years (pt.yrs) (mean patient follow-up: 3 years). All GLM-treated patients started at the $50 \mathrm{mg}$ dose and received a median (min$\max )$ of 16 (1-92) injections representing a total exposure of 1077 pt.yrs. (mean patient follow-up: 2 years). One patient received at least one $100 \mathrm{mg}$ dose, 11 patients (2.1\%) received $50 \mathrm{mg}$ injections at shorter than q28 days intervals while 82 patients $(15.6 \%)$ received $50 \mathrm{mg}$ injections at q28-32 days intervals throughout study. For
Table 1 Patient demographics and baseline characteristics

\begin{tabular}{|c|c|c|c|}
\hline & IFX & GLM & GLM-IV \\
\hline Number of Patients & 890 & 530 & 157 \\
\hline Female Gender, n (\%) & $\begin{array}{l}773 \\
(86.8 \%)\end{array}$ & $\begin{array}{l}404 \\
(76.2 \%)\end{array}$ & $\begin{array}{l}121 \\
(77.0 \%)\end{array}$ \\
\hline Mean (SD) Age, years & $55.8(13.5)$ & $57.7(13.0)$ & $56.3(12.3)$ \\
\hline Mean (SD) Weight, Kg & $75.4(19.22)$ & $76.8(19.4)$ & $78.4(21.8)$ \\
\hline $\begin{array}{l}\text { Positive Rheumatoid Factor, } \\
\%\end{array}$ & $68.4 \%$ & $60.4 \%$ & $58.6 \%$ \\
\hline \multicolumn{4}{|l|}{ Disease duration, years } \\
\hline Mean (SD) & $9.8(9.98)$ & $8.0(7.61)$ & $6.5(8.76)$ \\
\hline Median & 6.0 & 4.9 & 6.0 \\
\hline \multicolumn{4}{|l|}{ Number of previous DMARDs } \\
\hline Mean (SD) & $2.1(1.41)$ & $2.3(1.08)$ & $2.5(0.97)$ \\
\hline \multicolumn{4}{|l|}{ Previous Therapies, \% } \\
\hline DMARDs & $87.2 \%$ & $94.5 \%$ & $98.7 \%$ \\
\hline NSAIDs & $59.7 \%$ & $48.3 \%$ & $54.8 \%$ \\
\hline Corticosteroids & $47.9 \%$ & $52.8 \%$ & $46.5 \%$ \\
\hline Methotrexate & $70.4 \%$ & $84.7 \%$ & $92.4 \%$ \\
\hline \multicolumn{4}{|l|}{ Concomitant Therapies, \% } \\
\hline DMARDs & $89.3 \%$ & $88.6 \%$ & $88.5 \%$ \\
\hline NSAIDs & $53.4 \%$ & $43.8 \%$ & $49.0 \%$ \\
\hline Corticosteroids & $36.9 \%$ & $33.0 \%$ & $28.7 \%$ \\
\hline Methotrexate & $71.1 \%$ & $67.4 \%$ & $68.2 \%$ \\
\hline Bio-naive, \% & $93.7 \%$ & $86.2 \%$ & $80.3 \%$ \\
\hline DAS 28 CRP $^{a}$ & $5.3(1.37)$ & $4.5(1.2)$ & $4.1(1.0)$ \\
\hline DAS $28 E R^{a}$ & $5.7(1.49)$ & $4.7(1.40)$ & $4.4(1.16)$ \\
\hline TJC ${ }^{a}$ & $12.3(8.11)$ & $9.5(7.0)$ & $9.2(6.6)$ \\
\hline $\mathrm{SJC}^{\mathrm{a}}$ & $10.4(7.04)$ & $8.1(5.7)$ & $6.7(4.8)$ \\
\hline $\mathrm{PtGA}^{\mathrm{a}}$ & $60.2(24.12)$ & $56.8(25.2)$ & $59.2(25.2)$ \\
\hline MDGA $^{a}$ & $6.4(2.15)$ & $5.9(2.2)$ & $5.2(2.5)$ \\
\hline$H A Q^{a}$ & $1.6(0.70)$ & $1.3(0.7)$ & $1.3(0.7)$ \\
\hline Pain, VAS ${ }^{a}$ & $57.2(23.99)$ & $55.2(25.6)$ & $58.2(28.0)$ \\
\hline $\mathrm{CRP}, \mathrm{mg} / \mathrm{L}^{\mathrm{a}}$ & $18.2(23.42)$ & $15.4(31.4)$ & $20.1(37.4)$ \\
\hline $\mathrm{ESR}, \mathrm{mm} / \mathrm{hr}^{\mathrm{a}}$ & $32.2(24.16)$ & $24.2(20.6)$ & 26.4 (18.6) \\
\hline Morning stiffness, $\min ^{a}$ & $65.3(45.51)$ & $54.4(43.8)$ & $60.3(45.7)$ \\
\hline
\end{tabular}

${ }^{\mathrm{a}}$ Mean (SD)

GLM-IV, the mean (SD) dose was $1.97(0.56) \mathrm{mg} / \mathrm{Kg}$ over a median (min-max) of 11 (1-29) infusions representing a total exposure of 257 pt.yrs. (mean patient follow-up: 1.6 years).

As shown in Fig. 1, a significant decrease in baseline disease duration was observed in IFX-treated patients over the index year $(p<0.001)$. A similar reduction was also observed in baseline disease activity scores (DAS28 ESR, TJC, SJC, HAQ, AM stiffness, MDGA, PtGA, CRP, ESR) over the index year (Fig. 1 and Supplementary Material). In contrast, baseline disease duration and activity 


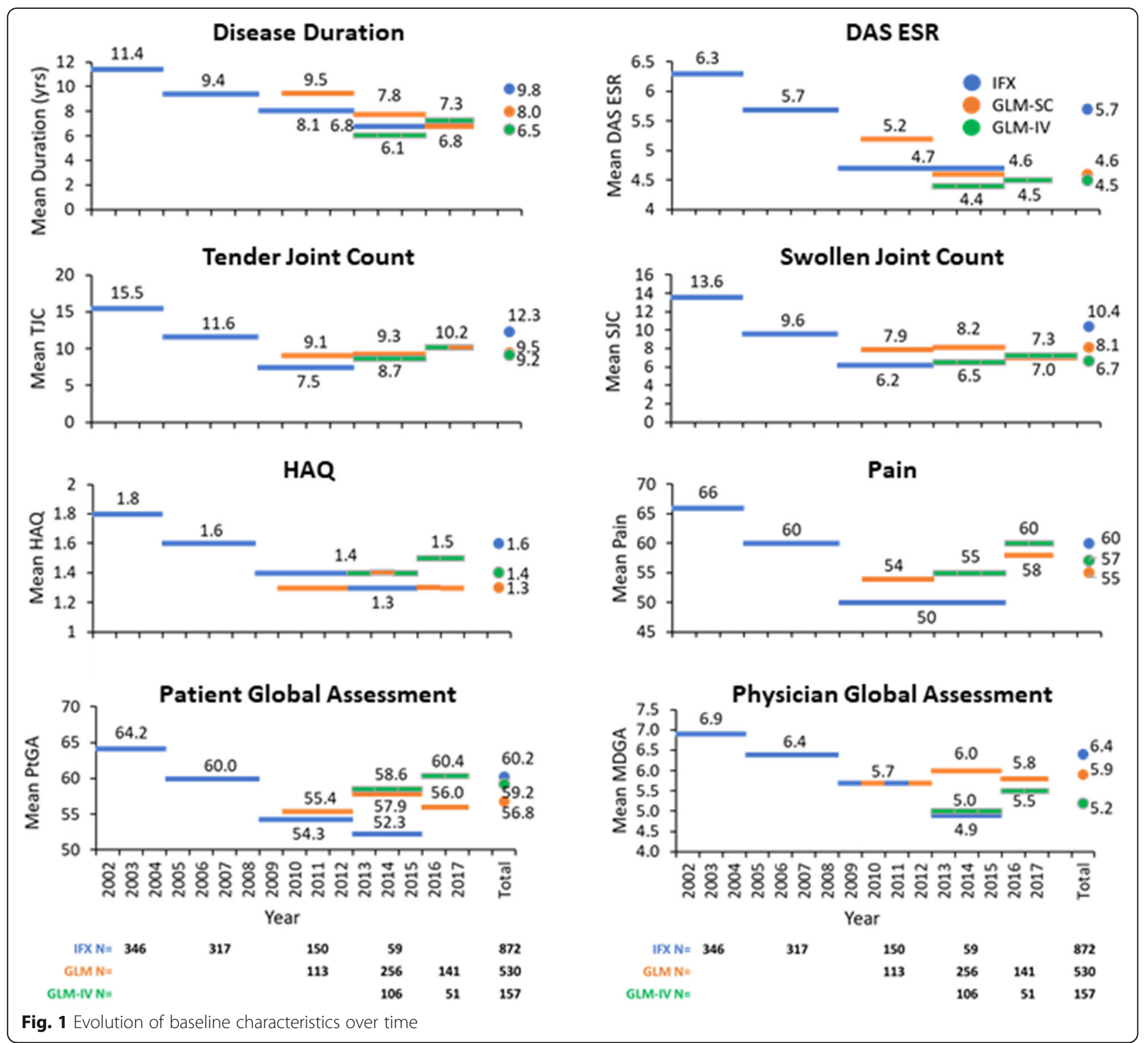

scores in the GLM- and GLM-IV-treated patients remained stable between 2010 and 2017. Interestingly, baseline disease duration and some of the disease activity scores (DAS28 ESR, TJC, SJC, PtGA, Pain, CRP, ESR) were higher in GLM-treated patients from the 20102012 time period when the drug was first introduced compared in IFX-treated patients despite the mean MDGA and HAQ being the same (Fig. 1).

Treatment with all three anti-TNFs significantly improved TJC, SJC, DAS28 CRP, HAQ, PtGA and MDGA scores from baseline to 6 months and up to 120,78 and 42 months for IFX, GLM and GLM-IV, respectively (Fig. 2). A similar effect was also observed for DAS28 ESR, pain, CRP and ESR (Fig. 3). However, achievement of target-specific outcomes appeared to differ between agents. Indeed, the proportion of patients in SDAI remission at 12, 24 and 36 months reached 16.2, 20.8 and $22.8 \%$ in IFX-patients; $34.7,47.5$ and $52.7 \%$ in GLMpatients and 33.8, 47.5 and $61.9 \%$ in GLM-IV-patients (Fig. 2). Similar patterns were observed with DAS28 remission and with CDAI LDA and remission (not shown).

The proportion of patients who discontinued treatment were $74.0 \%$ over a mean 3.0 years of exposure to IFX, $65.6 \%$ over 2.0 years of exposure to GLM and $45.2 \%$ over 1.6 year of exposure to GLM-IV. The median time to discontinuation was $24.9,33.4$ and 36.1 months for IFX, GLM and GLM-IV, respectively (Fig. 4). The reasons for discontinuations are shown in Table 2.

AEs were reported for 61.5, 67.4 and 59.2\% (105, 113 and 82.6 events/100 PYs) and SAEs for 21.2, 15.5 and 3.8\% (11.7, 11.2 and 4.68 events/100 PYs) covering 2714, 1077 and 257 years of exposure for IFX, GLM and GLM- 


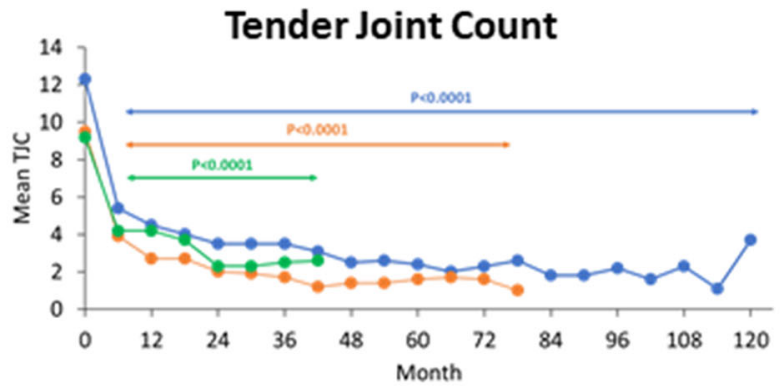

Oxk

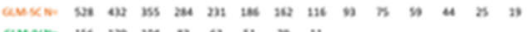

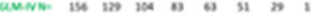

\section{DAS28 CRP}

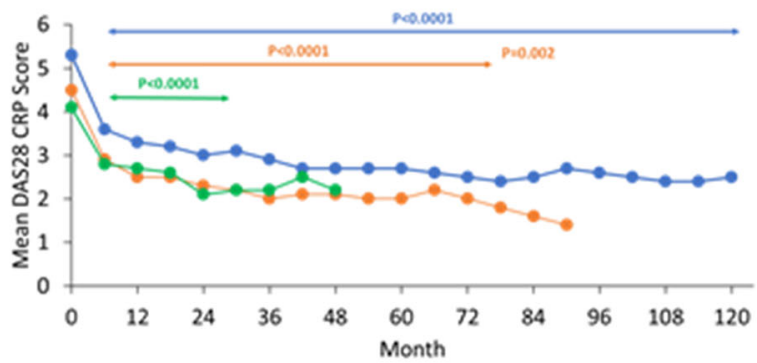

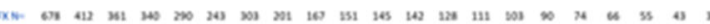

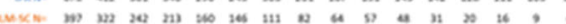

पy

\section{Patient Global Assessment}

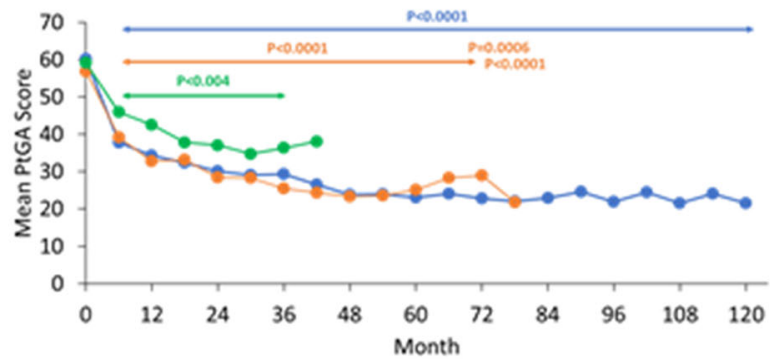

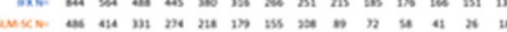

(a)

\section{SDAI Low Disease Activity}

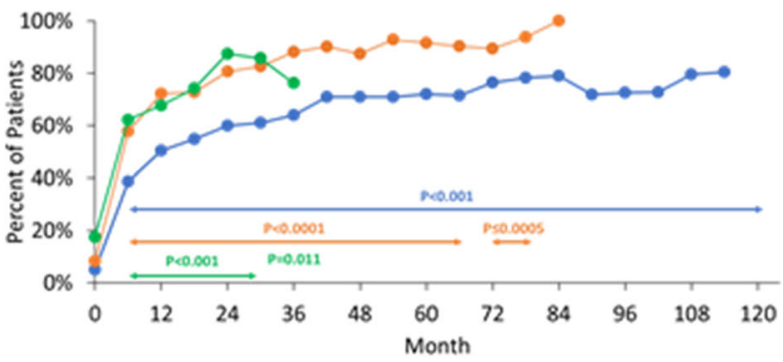

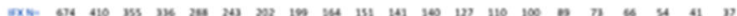

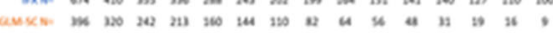

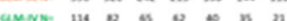

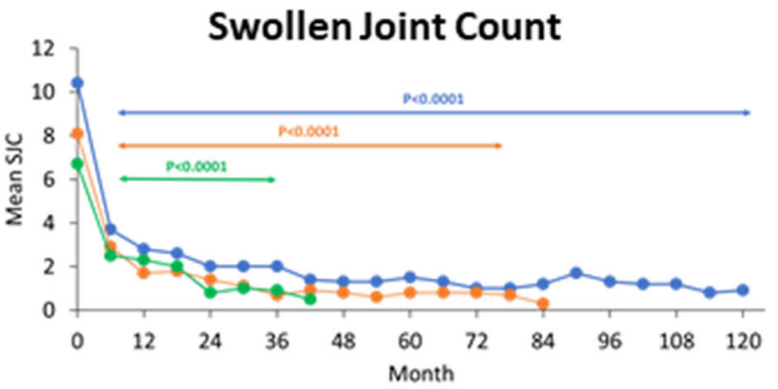

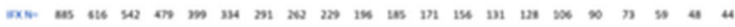

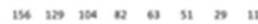

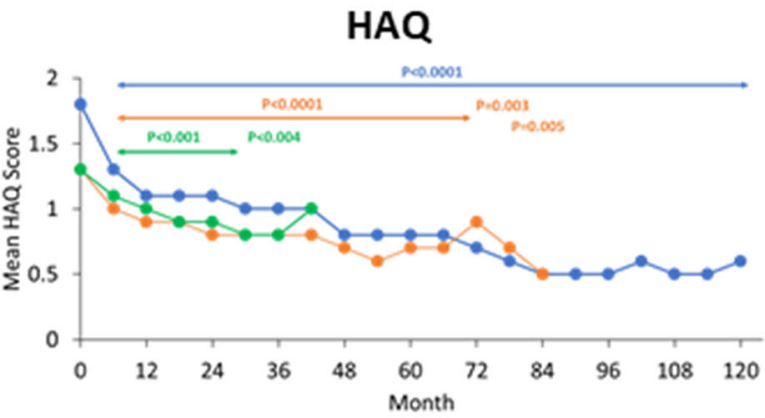

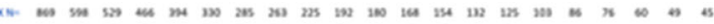
a

\section{Physician Global Assessment}

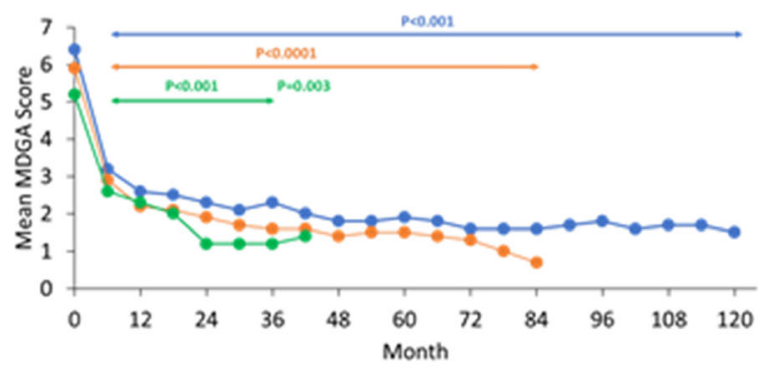

Exo- or w (n)

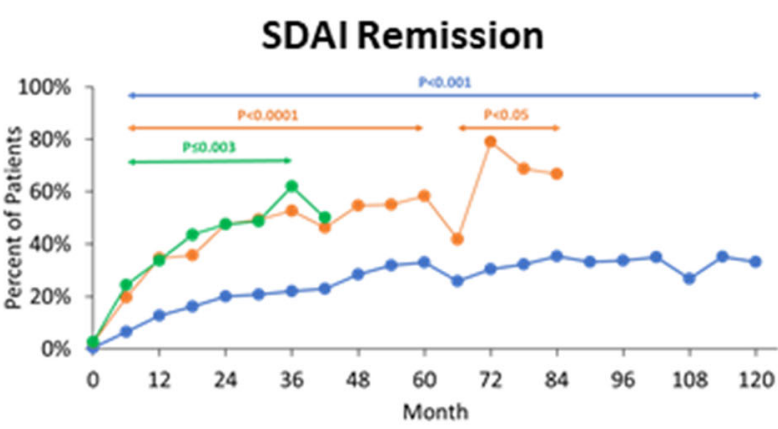

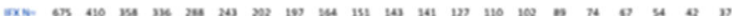

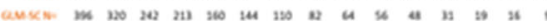

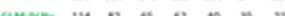

Fig. 2 Effect of treatment with IFX, GLM and GLM-IV on disease parameters over time. Observed data with X-axis cut at 120 months for clarity (goes up to 168 months for IFX; $n=4$ ). P value vs baseline 

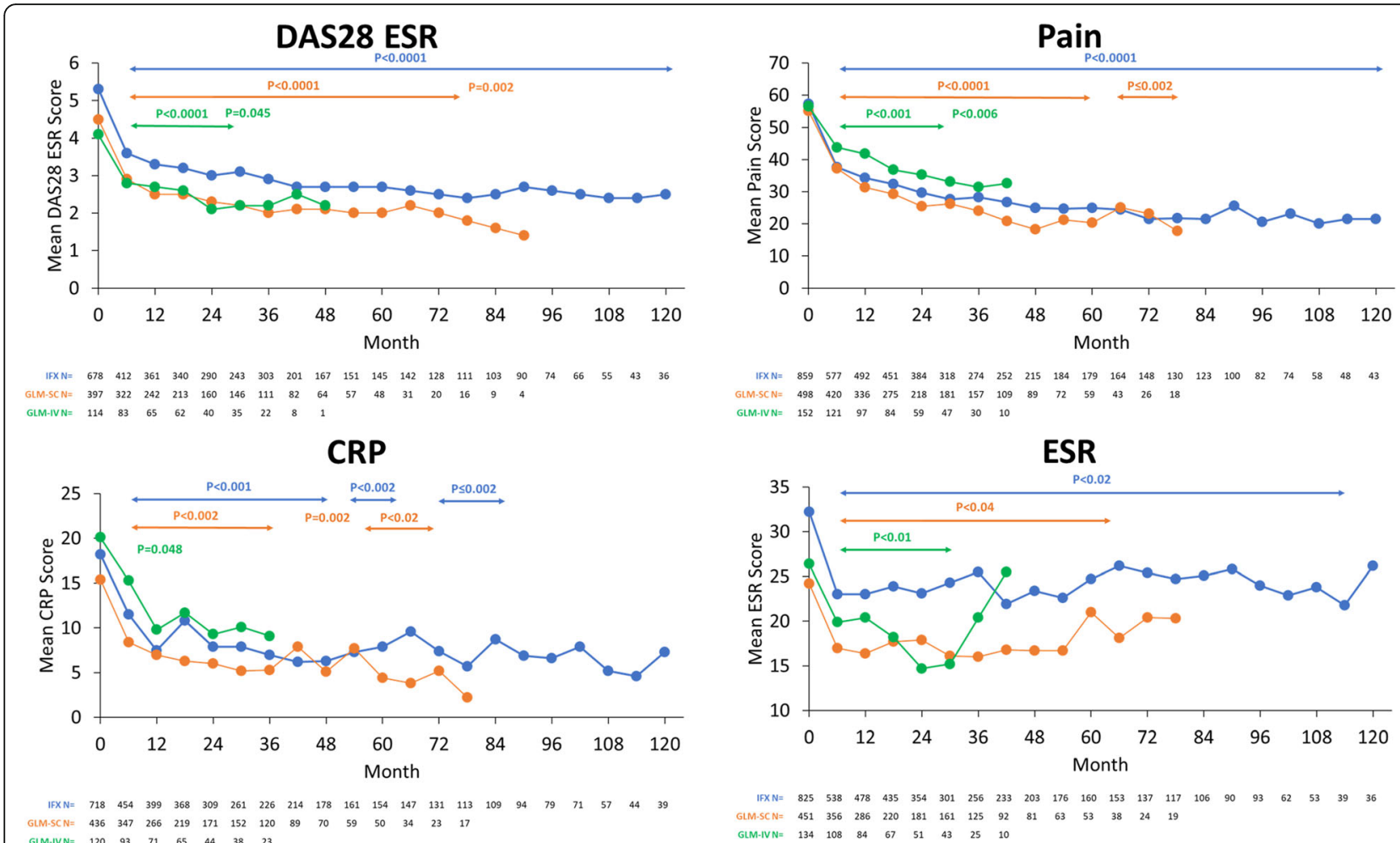

IFXN= $859 \begin{array}{llllllllllllllllllll}577 & 492 & 451 & 384 & 318 & 274 & 252 & 215 & 184 & 179 & 164 & 148 & 130 & 123 & 100 & 82 & 74 & 58 & 48 & 43\end{array}$

CM.SCN= $\begin{array}{lllllllllllllll}498 & 420 & 336 & 275 & 218 & 181 & 157 & 109 & 89 & 72 & 59 & 43 & 26 & 18\end{array}$ GLM-IVN= $\begin{array}{rllllllll}152 & 121 & 97 & 84 & 59 & 47 & 30 & 10\end{array}$

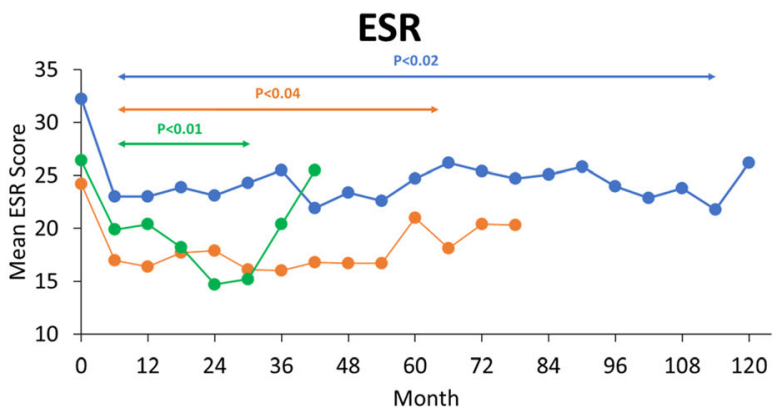

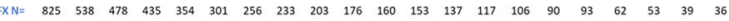

GLM-SCN= $\begin{array}{llllllllllllll}451 & 356 & 286 & 220 & 181 & 161 & 125 & 92 & 81 & 63 & 53 & 38 & 24 & 19\end{array}$

$G$ GLM-IVN= $\begin{array}{lllllllll}134 & 108 & 84 & 67 & 51 & 43 & 25 & 10\end{array}$

\section{IFX GLM GLM-IV}

Fig. 3 Effect of treatment with IFX, GLM and GLM-IV on disease parameters over time. Observed data with X-axis cut at 120 months for clarity (goes up to 168 months for IFX; $n=4)$. $P$ value vs baseline

IV-treated patients, respectively (Tables 3, 4 and 5). The most frequently occurring AEs were arthralgia and upper respiratory tract infection ( $>5 \%)$. The most common serious infection was pneumonia. Sixty (6.7\%) IFX-treated patients discontinued IFX due to an SAE. For GLM- and GLM-IV-treated patients, discontinuation due to an SAE occurred in $20(3.8 \%)$ and $2(1.3 \%)$ patients, respectively. There were 8 cases of opportunistic infections (including a new onset disseminated TB) in IFX-treated patients while none were observed in any GLM- or GLM-IVtreated patients. The incidence of malignancies, serious and opportunistic infections are further described in Table 6. In summary, the incidence rate of malignancies was similar between IFX- and GLM-treated patients (1.87/ and 2.41/100 pt.yrs., respectively) while only one case was reported in GLM-IV patients. There were three pregnancies in IFX-treated patients and two in GLMtreated patients (with 1 induced labor and 1 post-partum hemorrhage).

There were 18 deaths during the study among IFXtreated patients $(0.66 / 100$ pt.yrs). Cause of death included major adverse cardiovascular event (MACE; $\times 3$ ), lung cancer $(\times 2)$, pulmonary fibrosis $(\times 2)$, pneumonia $(\times 2)$, respiratory failure, bronchitis, intestinal cancer, throat cancer, intestinal gangrene, disseminated TB, septic shock, procedural complications and unknown (one of each). Seven GLM-treated patients also died (0.64/ 100 pt.yrs). Cause of death were MACE $(\times 3)$, lung cancer $(\times 2)$, and unknown $(\times 2)$. One GLM-IV patient died from a MACE $(0.25 / 100$ pt.yrs $)$.

\section{Discussion}

Differences are found in patient characteristics between registries and randomized control studies [4], and the former are essential to determine the effectiveness and safety of new therapies in a broad, generalizable population. In the past decades, national and regional registries were established to evaluate anti-TNF agents in the treatment of RA [10]. However, most evaluated the earliest agents, such as IFX and etanercept, and only a few published registries included data on the newer antiTNFs such as adalimumab [11, 12], certolizumab-pegol $[13,14]$ and GLM [15]. BioTRAC was one of the longest running RA registries and included data on both old (IFX) and new (GLM) anti-TNF agents. 


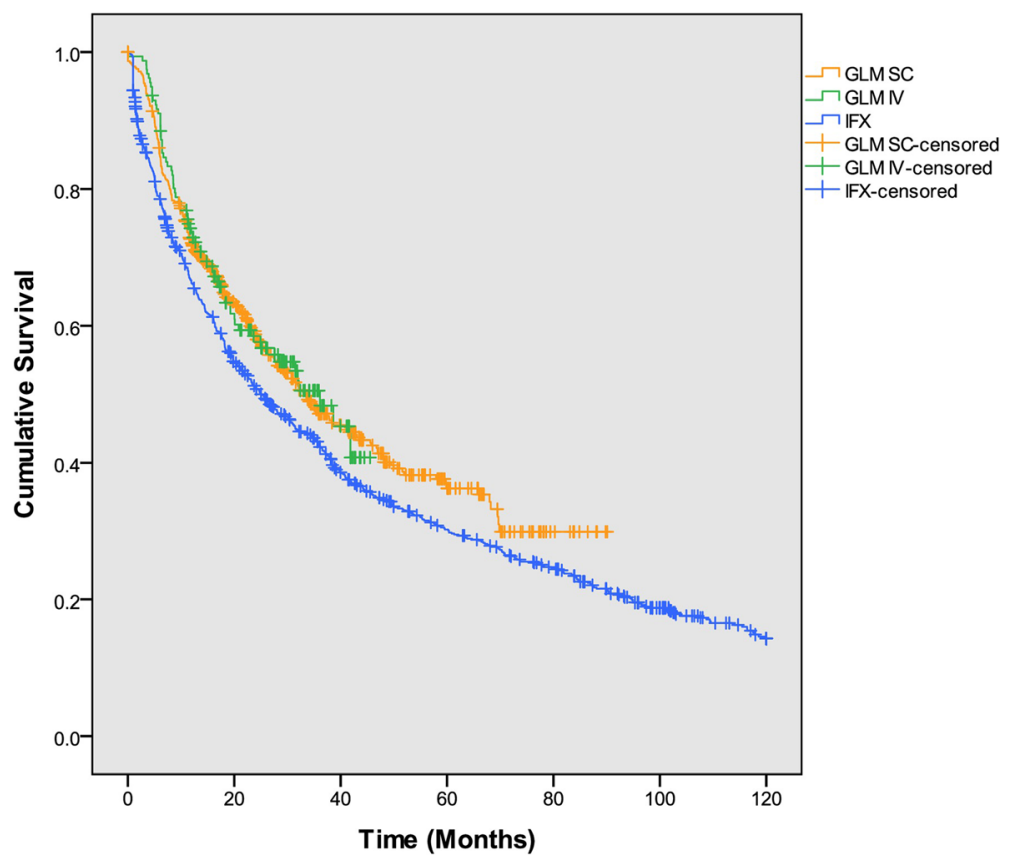

Fig. 4 Kaplan-Meier drug survival analysis

When anti-TNFs were first approved for the treatment of RA, they were initially used in more refractory patients with longer established disease and higher disease activity. As time passed, they were used earlier, in more moderate activity patients. This can be seen if one compares the baseline characteristics of patients in the registration studies for IFX and GLM [16, 17]. Such a pattern, in which baseline disease activity decreased over time, had been reported in the interim analysis of the IFX-treated patients in BioTRAC [6]. Despite this, it was interesting to notice that baseline disease characteristics of the GLM-treated patients from 2010 to 2012 suggest that the first patients to be treated with GLM may have had more active disease than IFX-treated patients. This could be the result of an unconscious channeling bias towards using newer therapies in more severe patients, as the MDGA scores were identical between the two cohorts. Another possibility is that this was driven by the limited availability of the GLM auto-injector during that period, forcing the use of pre-filled syringes by most patients, along with uncertainties in market dynamics caused by the corporate takeover of Schering-Plough by Merck and the subsequent transition of the immunology portfolio to Janssen. Studies to evaluate the impact of disease duration, baseline disease activity and the adherence to treat-to-target guidelines on long-term function and outcomes are ongoing.

Despite difference in baseline disease activity, all three anti-TNFs showed efficacy with decreased disease activity and improved function. The route of administration does not appear to bring any specific efficacy benefit, as the data curves for GLM and GLM-IV patients are basically superimposable. Differences in the proportion of patients achieving target-specific outcomes such as LDA and remission were noted between IFX- and GLM -/GLM-IV-treated patients. Because we are reporting observed data, these differences could be driven by differences in baseline disease activity, the implementation of treat-to-target guidelines or the use of more stringent targets, such as remission rather than LDA, in later years when GLM and GLM-IV were more likely to be chosen as treatment. Also, the greater availability of additional treatment options could lead to a higher probability of switching therapies if such targets were not achieved. Therefore, caution should be exercised when interpreting the relative effectiveness of the three agents.

The incidence of AEs and SAEs was found to be similar between agents, although there were some notable differences. Patients treated with IFX had a greater incidence of chest discomfort, chest pain, fatigue, headaches, pain, pyrexia, pain in extremities and pruritus compared to GLM and GLM-IV patients, all of which could be due to acute and delayed infusion reactions [18]. Conversely, GLM and GLM-IV patients had a greater incidence of "lack of response" or "loss of response" AEs compared to IFX-treated patients, although this was likely driven by changes in the "End Of Participation" questionnaire and the addition of lack/ loss of response as an $\mathrm{AE}$ of special interest in a protocol amendment after 2014 (see below). 
Table 2 Discontinuations and reasons for discontinuations*

\begin{tabular}{|c|c|c|c|}
\hline & IFX & GLM & GLM-IV \\
\hline Total discontinuations (n/N, \%) & $659 / 890,74.0 \%$ & $280 / 530,65.6 \%$ & $71 / 157,45.2 \%$ \\
\hline Exposure (Total, Mean pt. yrs) & $2714,3.0$ & $1077,2.0$ & $257,1.6$ \\
\hline \multicolumn{4}{|l|}{ Reason for discontinuation $\left(n, \%^{a}\right)$} \\
\hline Patient withdrew consent & $58,8.8 \%$ & $25,8.9 \%$ & $4,5.6 \%$ \\
\hline Adverse event & $116,17.6 \%$ & $33,11.8 \%$ & $10,14.1 \%$ \\
\hline Lost to follow-up & $25,3.8 \%$ & $28,10.0 \%$ & $7,9.9 \%$ \\
\hline Financial reasons & $14,2.1 \%$ & $4,1.4 \%$ & $0,0.0 \%$ \\
\hline Complete response & $10,1.5 \%$ & $4,1.4 \%$ & $0,0.0 \%$ \\
\hline Disease progression & $75,11.4 \%$ & $14,5.0 \%$ & $2,2.8 \%$ \\
\hline Lack of response & $45,6.8 \%$ & $67,23.9 \%$ & $22,31.0 \%$ \\
\hline Loss of response & $65,9.9 \%$ & $46,16.4 \%$ & $6,8.5 \%$ \\
\hline Unusual lack of efficacy & $0,0 \%$ & $1,0.4 \%$ & $0,0 \%$ \\
\hline Geographic issues & $24,3.6 \%$ & $3,1.1 \%$ & $2,2.8 \%$ \\
\hline Patient switched to another therapy & $32,4.9 \%$ & $15,5.4 \%$ & $9,12.7 \%$ \\
\hline Did not meet entry criteria & $1,0.2 \%$ & $0,0.0 \%$ & $0,0.0 \%$ \\
\hline Other & $191,29.0 \%$ & $40,14.3 \%$ & $8,11.3 \%$ \\
\hline Missing & $3,0.5 \%$ & $0,0 \%$ & $1,1.4 \%$ \\
\hline
\end{tabular}

a Proportions based on number of discontinued patients

Table 3 Adverse events occurring in $\geq 4 \%$ of patients per agent

\begin{tabular}{|c|c|c|c|c|c|c|c|c|c|c|c|c|}
\hline \multirow{3}{*}{$\begin{array}{l}\text { Exposure (Total, Mean pt.yrs) } \\
\text { SOC }\end{array}$} & \multicolumn{4}{|c|}{$\operatorname{IFX}(\boldsymbol{N}=890)$} & \multicolumn{4}{|c|}{$\operatorname{GLM}(\boldsymbol{N}=530)$} & \multicolumn{4}{|c|}{ GLM-IV $(\boldsymbol{N}=157)$} \\
\hline & \multicolumn{4}{|c|}{$2714,3.0$} & \multicolumn{4}{|c|}{$1077,2.0$} & \multicolumn{4}{|l|}{$257,1.6$} \\
\hline & $\begin{array}{l}\mathrm{N} \text { of } \\
\text { Events }\end{array}$ & $\begin{array}{l}\mathrm{N} \text { of } \\
\text { Patients }\end{array}$ & $\begin{array}{l}\% \text { of } \\
\text { Patients }\end{array}$ & $\begin{array}{l}\text { Rate/100 } \\
\text { Pt-Yrs }\end{array}$ & $\begin{array}{l}\mathrm{N} \text { of } \\
\text { Events }\end{array}$ & $\begin{array}{l}\mathrm{N} \text { of } \\
\text { Patients }\end{array}$ & $\begin{array}{l}\% \text { of } \\
\text { Patients }\end{array}$ & $\begin{array}{l}\text { Rate/100 } \\
\text { Pt-Yrs }\end{array}$ & $\begin{array}{l}\mathrm{N} \text { of } \\
\text { Events }\end{array}$ & $\begin{array}{l}\mathrm{N} \text { of } \\
\text { Patients }\end{array}$ & $\begin{array}{l}\% \text { of } \\
\text { Patients }\end{array}$ & $\begin{array}{l}\text { Rate/100 } \\
\text { Pt-Yrs }\end{array}$ \\
\hline Total & 3017 & 547 & $61.5 \%$ & 105 & 1212 & 357 & $67.4 \%$ & 113 & 212 & 93 & $59.2 \%$ & 82.6 \\
\hline Cardiac disorders & 45 & 39 & $4.4 \%$ & 1.56 & 20 & 16 & $3.0 \%$ & 1.86 & 1 & 1 & $0.6 \%$ & 0.39 \\
\hline Eye disorders & 73 & 47 & $5.3 \%$ & 2.53 & 25 & 15 & $2.8 \%$ & 2.32 & 2 & 2 & $1.3 \%$ & 0.78 \\
\hline Gastrointestinal disorders & 193 & 112 & $12.6 \%$ & 6.69 & 73 & 52 & $9.8 \%$ & 6.78 & 12 & 7 & $4.5 \%$ & 4.68 \\
\hline $\begin{array}{l}\text { General disorders and } \\
\text { administration site conditions }\end{array}$ & 297 & 175 & $19.7 \%$ & 10.3 & 169 & 148 & $27.9 \%$ & 15.7 & 40 & 38 & $24.2 \%$ & 15.6 \\
\hline Infections and infestations & 689 & 275 & $30.9 \%$ & 23.9 & 378 & 173 & $32.6 \%$ & 35.1 & 62 & 36 & $22.9 \%$ & 24.2 \\
\hline $\begin{array}{l}\text { Injury, poisoning and } \\
\text { procedural complications }\end{array}$ & 178 & 108 & $12.1 \%$ & 6.17 & 56 & 36 & $6.8 \%$ & 5.2 & 17 & 11 & $7.0 \%$ & 6.62 \\
\hline Investigations & 7 & 58 & $6.5 \%$ & 2.56 & 13 & 10 & $1.9 \%$ & 1.21 & 5 & 4 & $2.5 \%$ & 1.95 \\
\hline $\begin{array}{l}\text { Musculoskeletal and connective } \\
\text { tissue disorders }\end{array}$ & 486 & 152 & $17.1 \%$ & 16.8 & 130 & 84 & $15.8 \%$ & 12.1 & 17 & 11 & $7.0 \%$ & 6.62 \\
\hline $\begin{array}{l}\text { Neoplasms benign, malignant } \\
\text { and unspecified }\end{array}$ & 54 & 46 & $5.2 \%$ & 1.87 & 26 & 23 & $4.3 \%$ & 2.41 & 1 & 1 & $0.6 \%$ & 0.39 \\
\hline Nervous system disorders & 166 & 107 & $12.0 \%$ & 5.75 & 64 & 48 & $9.1 \%$ & 5.94 & 8 & 6 & $3.8 \%$ & 3.12 \\
\hline Psychiatric disorders & 19 & 17 & $1.9 \%$ & 0.66 & 10 & 10 & $1.9 \%$ & 0.93 & 2 & 2 & $1.3 \%$ & 0.78 \\
\hline $\begin{array}{l}\text { Respiratory, thoracic and } \\
\text { mediastinal disorders }\end{array}$ & 226 & 131 & $14.7 \%$ & 7.83 & 73 & 44 & $8.3 \%$ & 6.78 & 15 & 10 & $6.4 \%$ & 5.84 \\
\hline $\begin{array}{l}\text { Skin and subcutaneous tissue } \\
\text { disorders }\end{array}$ & 260 & 160 & $18.0 \%$ & 9.01 & 83 & 57 & $10.8 \%$ & 7.71 & 14 & 11 & $7.0 \%$ & 5.45 \\
\hline $\begin{array}{l}\text { Surgical and medical } \\
\text { procedures }\end{array}$ & 42 & 38 & $4.3 \%$ & 1.45 & 10 & 9 & $1.7 \%$ & 0.93 & 1 & 1 & $0.6 \%$ & 0.39 \\
\hline Vascular disorders & 90 & 63 & $7.1 \%$ & 3.12 & 14 & 14 & $2.6 \%$ & 1.3 & 1 & 1 & $0.6 \%$ & 0.39 \\
\hline
\end{tabular}


Table 4 Serious adverse events occurring in $\geq 0.5 \%$ of patients per agent

\begin{tabular}{|c|c|c|c|c|c|c|c|c|c|c|c|c|}
\hline \multirow{3}{*}{$\begin{array}{l}\text { Exposure (Total, Mean pt.yrs) } \\
\text { soC }\end{array}$} & \multicolumn{4}{|c|}{ IFX $(\boldsymbol{N}=890)$} & \multicolumn{4}{|c|}{ GLM $(\boldsymbol{N}=530)$} & \multicolumn{4}{|c|}{ GLM-IV $(\boldsymbol{N}=157)$} \\
\hline & \multicolumn{4}{|c|}{$2714,3.0$} & \multicolumn{4}{|c|}{$1077,2.0$} & \multicolumn{4}{|c|}{$257,1.6$} \\
\hline & $\begin{array}{l}\mathrm{N} \text { of } \\
\text { Events }\end{array}$ & $\begin{array}{l}\mathrm{N} \text { of } \\
\text { Patients }\end{array}$ & $\begin{array}{l}\% \text { of } \\
\text { Patients }\end{array}$ & $\begin{array}{l}\text { Rate/100 } \\
\text { Pt-Yrs }\end{array}$ & $\begin{array}{l}\mathrm{N} \text { of } \\
\text { Events }\end{array}$ & $\begin{array}{l}\mathrm{N} \text { of } \\
\text { Patients }\end{array}$ & $\begin{array}{l}\% \text { of } \\
\text { Patients }\end{array}$ & $\begin{array}{l}\text { Rate/100 } \\
\text { Pt-Yrs }\end{array}$ & $\begin{array}{l}\mathrm{N} \text { of } \\
\text { Events }\end{array}$ & $\begin{array}{l}\mathrm{N} \text { of } \\
\text { Patients }\end{array}$ & $\begin{array}{l}\% \text { of } \\
\text { Patients }\end{array}$ & $\begin{array}{l}\text { Rate/100 } \\
\text { Pt-Yrs }\end{array}$ \\
\hline Total & 338 & 189 & $21.2 \%$ & 11.7 & 121 & 82 & $15.5 \%$ & 11.2 & 12 & 6 & $3.8 \%$ & 4.68 \\
\hline Cardiac disorders & 20 & 18 & $2.0 \%$ & 0.69 & 12 & 10 & $1.9 \%$ & 1.11 & 0 & 0 & 0 & 0 \\
\hline Gastrointestinal disorders & 12 & 10 & $1.1 \%$ & 0.42 & 5 & 4 & $0.8 \%$ & 0.46 & 2 & 1 & $0.6 \%$ & 0.78 \\
\hline $\begin{array}{l}\text { General disorders and } \\
\text { administration site conditions }\end{array}$ & 20 & 19 & $2.1 \%$ & 0.69 & 7 & 7 & $1.3 \%$ & 0.65 & 1 & 1 & $0.6 \%$ & 0.39 \\
\hline Infections and infestations & 77 & 58 & $6.5 \%$ & 2.67 & 24 & 20 & $3.8 \%$ & 2.23 & 3 & 2 & $1.3 \%$ & 1.17 \\
\hline $\begin{array}{l}\text { Injury, poisoning and } \\
\text { procedural complications }\end{array}$ & 30 & 21 & $2.4 \%$ & 1.04 & 12 & 7 & $1.3 \%$ & 1.11 & 1 & 1 & $0.6 \%$ & 0.39 \\
\hline $\begin{array}{l}\text { Metabolism and nutrition } \\
\text { disorders }\end{array}$ & 8 & 5 & $0.6 \%$ & 0.28 & 1 & 1 & $0.2 \%$ & 0.09 & 0 & 0 & 0 & 0 \\
\hline $\begin{array}{l}\text { Musculoskeletal and connective } \\
\text { tissue disorders }\end{array}$ & 37 & 25 & $2.8 \%$ & 1.28 & 12 & 10 & $1.9 \%$ & 1.11 & 0 & 0 & 0 & 0 \\
\hline $\begin{array}{l}\text { Neoplasms benign, malignant } \\
\text { and unspecified }\end{array}$ & 45 & 40 & $4.5 \%$ & 1.56 & 16 & 14 & $2.6 \%$ & 1.49 & 1 & 1 & $0.6 \%$ & 0.39 \\
\hline Nervous system disorders & 18 & 16 & $1.8 \%$ & 0.62 & 10 & 9 & $1.7 \%$ & 0.93 & 1 & 1 & $0.6 \%$ & 0.39 \\
\hline Renal and urinary disorders & 2 & 2 & $0.2 \%$ & 0.07 & 4 & 3 & $0.6 \%$ & 0.37 & 0 & 0 & 0 & 0 \\
\hline $\begin{array}{l}\text { Respiratory, thoracic and } \\
\text { mediastinal disorders }\end{array}$ & 25 & 20 & $2.2 \%$ & 0.87 & 3 & 3 & $0.6 \%$ & 0.28 & 1 & 1 & $0.6 \%$ & 0.39 \\
\hline $\begin{array}{l}\text { Skin and subcutaneous tissue } \\
\text { disorders }\end{array}$ & 5 & 5 & $0.6 \%$ & 0.17 & 2 & 2 & $0.4 \%$ & 0.19 & 1 & 1 & $0.6 \%$ & 0.39 \\
\hline $\begin{array}{l}\text { Surgical and medical } \\
\text { procedures }\end{array}$ & 10 & 9 & $1.0 \%$ & 0.35 & 1 & 1 & $0.2 \%$ & 0.09 & 1 & 1 & $0.6 \%$ & 0.39 \\
\hline Vascular disorders & 9 & 8 & $0.9 \%$ & 0.31 & 0 & 0 & 0 & 0 & 1 & 1 & $0.6 \%$ & 0.39 \\
\hline Cardiac disorders & 20 & 18 & $2.0 \%$ & 0.69 & 12 & 10 & $1.9 \%$ & 1.11 & 0 & 0 & 0 & 0 \\
\hline
\end{tabular}

The incidence of serious infections was 1.2-2.7 events/100 pt.yrs., slightly lower than the incidence of 44.4 events/100 pt.yrs. reported in other registries [10, 11, 19]. However, since anti-TNF therapy in RA patients was associated with an increased risk of serious infections, especially in the first 6 months of treatment [20, 21 , registries with very long duration of follow-up would have a tendency to report a lower incidence rate. The low incidence of serious infection could also be explained by the low level of disease activity achieved and maintained over time. Indeed, the CORRONA registry assessed the relationship between DAS28 and infection in RA patients and found that high disease activity was associated with an increased risk of infection [22]. Analyses from the BSRBR and Italian LORHEN registries showed similar results [20, 23]. However, other European registries suggested that higher disease activity as measured by DAS28 was not directly associated with an increased incidence of serious infections [24]. Post Hoc analyses could be done in order to determine if serious infections are linked to control of disease activity, age, the use of concomitant MTX, glucocorticoids or survival bias from dropout of patients who developed an infection and subsequently stopped their anti-TNF.

The limitations of this registry are the absence of a non-biologic DMARD control group, the inclusion of predominantly bio-naïve patients and the inherent biases that are common within non-interventional, observational studies. Other limitations are related to non-inclusion of specific data sets that were not "standard of care" among community clinics in the mid2000 's as this would have led to many missing data points. Examples of these includes radiographic imaging, the complete $66 / 68$ joint count and baseline comorbidities (although smoking habits were recorded since 2009). Also, the long duration of the registry could have had an impact on data quality over time due to protocol amendments, changes in standard operating procedures from the three sponsors and improvements in adverse event reporting from refining processes and increasing site experience. An example of the above was site training implemented in 2014 following the first interim analysis of the IFX cohort [6] to limit the inappropriate use of the "Other reason; provide details" 
Table 5 Adverse events (preferred term; $\geq 2$ patients with one agent)

\begin{tabular}{|c|c|c|c|c|c|c|c|c|c|c|c|c|}
\hline & \multicolumn{4}{|c|}{ IFX $(\boldsymbol{N}=890)$} & \multicolumn{4}{|c|}{$\operatorname{GLM}(\boldsymbol{N}=530)$} & \multicolumn{4}{|c|}{ GLM-IV $(\boldsymbol{N}=157)$} \\
\hline & $\begin{array}{l}\mathrm{N} \text { of } \\
\text { Events }\end{array}$ & $\begin{array}{l}\mathrm{N} \text { of } \\
\text { Patients }\end{array}$ & $\begin{array}{l}\% \text { of } \\
\text { Patients }\end{array}$ & $\begin{array}{l}\text { Rate/100 } \\
\text { Pt-Yrs }\end{array}$ & $\begin{array}{l}\mathrm{N} \text { of } \\
\text { Events }\end{array}$ & $\begin{array}{l}\mathrm{N} \text { of } \\
\text { Patients }\end{array}$ & $\begin{array}{l}\% \text { of } \\
\text { Patients }\end{array}$ & $\begin{array}{l}\text { Rate/100 } \\
\text { Pt-Yrs }\end{array}$ & $\begin{array}{l}\mathrm{N} \text { of } \\
\text { Events }\end{array}$ & $\begin{array}{l}\mathrm{N} \text { of } \\
\text { Patients }\end{array}$ & $\begin{array}{l}\% \text { of } \\
\text { Patients }\end{array}$ & $\begin{array}{l}\text { Rate/ } \\
\text { Pt-Yr }\end{array}$ \\
\hline \multicolumn{13}{|c|}{ Gastrointestinal disorders } \\
\hline Diarrhea & 27 & 20 & $2.2 \%$ & 0.94 & 12 & 12 & $2.3 \%$ & 1.11 & 1 & 1 & $0.6 \%$ & 0.39 \\
\hline Nausea & 54 & 44 & $4.9 \%$ & 1.87 & 13 & 12 & $2.3 \%$ & 1.21 & 2 & 2 & $1.3 \%$ & 0.78 \\
\hline Vomiting & 23 & 20 & $2.2 \%$ & 0.80 & 7 & 7 & $1.3 \%$ & 0.65 & 1 & 1 & $0.6 \%$ & 0.39 \\
\hline
\end{tabular}

General disorders and administration site conditions

Chest discomfort
Chest pain
Drug effect decreased
Drug ineffective
Fatigue
Influenza-like illness
Pain
Pyrexia
Therapeutic response
decreased

$\begin{array}{llll}26 & 22 & 2.5 \% & 0.90 \\ 21 & 19 & 2.1 \% & 0.73 \\ 5 & 5 & 0.6 \% & 0.17 \\ 19 & 19 & 2.1 \% & 0.66 \\ 41 & 33 & 3.7 \% & 1.42 \\ 15 & 11 & 1.2 \% & 0.52 \\ 23 & 20 & 2.2 \% & 0.80 \\ 27 & 26 & 2.9 \% & 0.94 \\ 22 & 22 & 2.5 \% & 0.76\end{array}$

$\begin{array}{llllllll}0 & 0 & 0 & 0 & 0 & 0 & 0 & 0 \\ 2 & 2 & 0.4 \% & 0.19 & 1 & 1 & 0.6 \% & 0.39 \\ 22 & 22 & 4.2 \% & 2.04 & 6 & 6 & 3.8 \% & 2.34 \\ 64 & 63 & 11.9 \% & 5.94 & 23 & 23 & 14.6 \% & 8.96 \\ 5 & 5 & 0.9 \% & 0.46 & 3 & 3 & 1.9 \% & 1.17 \\ 16 & 15 & 2.8 \% & 1.49 & 3 & 3 & 1.9 \% & 1.17 \\ 3 & 3 & 0.6 \% & 0.28 & 0 & 0 & 0 & 0 \\ 4 & 4 & 0.8 \% & 0.37 & 1 & 1 & 0.6 \% & 0.39 \\ 23 & 23 & 4.3 \% & 2.14 & 1 & 1 & 0.6 \% & 0.39\end{array}$

\section{Infections and infestations}

\begin{tabular}{|c|c|c|c|c|c|c|c|c|c|c|c|c|}
\hline Bronchitis & 51 & 41 & $4.6 \%$ & 1.77 & 18 & 17 & $3.2 \%$ & 1.67 & 5 & 5 & $3.2 \%$ & 1.95 \\
\hline Ear infection & 21 & 14 & $1.6 \%$ & 0.73 & 11 & 10 & $1.9 \%$ & 1.02 & 4 & 4 & $2.5 \%$ & 1.56 \\
\hline Herpes Zoster & 19 & 19 & $2.1 \%$ & 0.66 & 14 & 13 & $2.5 \%$ & 1.3 & 1 & 1 & $0.6 \%$ & 0.39 \\
\hline Influenza & 36 & 29 & $3.3 \%$ & 1.25 & 13 & 10 & $2.1 \%$ & 1.21 & 0 & 0 & 0 & 0 \\
\hline Pneumonia & 47 & 41 & $4.6 \%$ & 1.63 & 13 & 11 & $2.1 \%$ & 1.21 & 2 & 2 & $1.3 \%$ & 0.78 \\
\hline Sinusitis & 53 & 31 & $3.5 \%$ & 1.84 & 14 & 13 & $2.5 \%$ & 1.3 & 8 & 6 & $3.8 \%$ & 3.12 \\
\hline $\begin{array}{l}\text { Upper respiratory tract } \\
\text { infection }\end{array}$ & 72 & 49 & $5.5 \%$ & 2.49 & 57 & 45 & $8.5 \%$ & 5.29 & 3 & 3 & $1.9 \%$ & 1.17 \\
\hline Urinary tract infection & 51 & 32 & $3.6 \%$ & 1.77 & 32 & 23 & $4.3 \%$ & 2.97 & 6 & 6 & $3.8 \%$ & 2.34 \\
\hline $\begin{array}{l}\text { Injury, poisoning and } \\
\text { procedural complications }\end{array}$ & 178 & 108 & $12.1 \%$ & 6.17 & 56 & 36 & $6.8 \%$ & 5.2 & 17 & 11 & $7.0 \%$ & 6.62 \\
\hline Fall & 24 & 21 & $2.4 \%$ & 0.83 & 9 & 9 & $1.7 \%$ & 0.84 & 9 & 4 & $2.5 \%$ & 3.51 \\
\hline Infusion-related reaction & 53 & 37 & $4.2 \%$ & 1.84 & 0 & 0 & 0 & 0 & 0 & 0 & 0 & 0 \\
\hline $\begin{array}{l}\text { Musculoskeletal and } \\
\text { connective tissue disorders }\end{array}$ & 486 & 152 & $17.1 \%$ & 16.8 & 130 & 84 & $15.8 \%$ & 12.1 & 17 & 11 & $7.0 \%$ & 6.62 \\
\hline Arthralgia & 150 & 60 & $6.7 \%$ & 5.20 & 24 & 19 & $3.6 \%$ & 2.23 & 5 & 5 & $3.2 \%$ & 1.95 \\
\hline Back pain & 30 & 26 & $2.9 \%$ & 1.04 & 7 & 6 & $1.1 \%$ & 0.65 & 0 & 0 & 0 & 0 \\
\hline Pain in extremity & 65 & 30 & $3.4 \%$ & 2.25 & 4 & 4 & $0.8 \%$ & 0.37 & 2 & 2 & $1.3 \%$ & 0.78 \\
\hline Osteoarthritis & 26 & 18 & $2.0 \%$ & 0.90 & 17 & 14 & $2.6 \%$ & 1.58 & 0 & 0 & 0 & 0 \\
\hline Rheumatoid arthritis & 57 & 37 & $4.2 \%$ & 1.97 & 18 & 16 & $3.0 \%$ & 1.67 & 3 & 3 & $1.9 \%$ & 1.17 \\
\hline Nervous system disorders & 166 & 107 & $12.0 \%$ & 5.75 & 64 & 48 & $9.1 \%$ & 5.94 & 8 & 6 & $3.8 \%$ & 3.12 \\
\hline Dizziness & 29 & 23 & $2.6 \%$ & 1.00 & 5 & 5 & $0.9 \%$ & 0.46 & 1 & 1 & $0.6 \%$ & 0.39 \\
\hline Headache & 61 & 44 & $4.9 \%$ & 2.11 & 10 & 11 & $1.9 \%$ & 1.02 & 1 & 1 & $0.6 \%$ & 0.39 \\
\hline $\begin{array}{l}\text { Respiratory, thoracic and } \\
\text { mediastinal disorders }\end{array}$ & 226 & 131 & $14.7 \%$ & 7.83 & 73 & 44 & $8.3 \%$ & 6.78 & 15 & 10 & $6.4 \%$ & 5.84 \\
\hline Cough & 40 & 28 & $3.1 \%$ & 1.39 & 21 & 16 & $3.0 \%$ & 1.95 & 3 & 3 & $1.9 \%$ & 1.17 \\
\hline $\begin{array}{l}\text { Skin and subcutaneous } \\
\text { tissue disorders }\end{array}$ & 260 & 160 & $18.0 \%$ & 9.01 & 83 & 57 & $10.8 \%$ & 7.71 & 14 & 11 & $7.0 \%$ & 5.45 \\
\hline Pruritus & 35 & 32 & $3.6 \%$ & 1.21 & 2 & 2 & $0.4 \%$ & 0.19 & 1 & 1 & $0.6 \%$ & 0.39 \\
\hline
\end{tabular}


Table 5 Adverse events (preferred term; $\geq 2$ patients with one agent) (Continued)

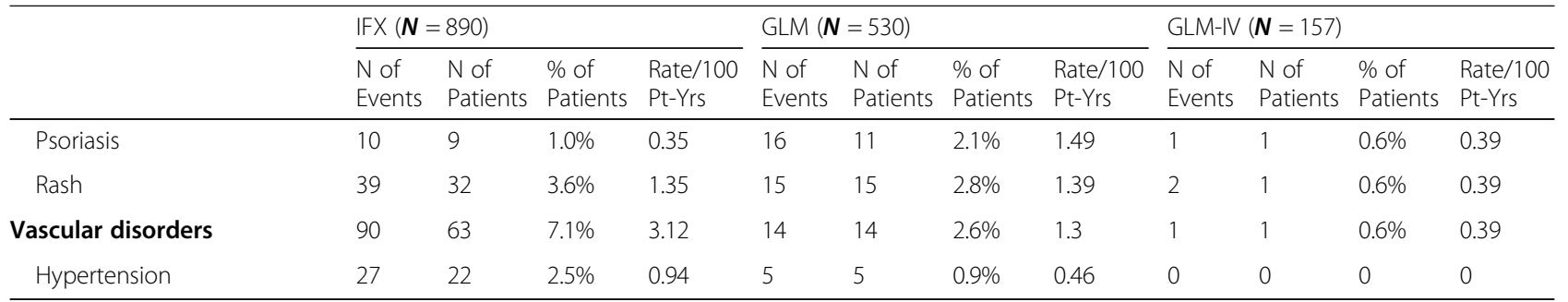

box within the "End of participation" form when patients were losing response. This led to an increase in the incidence of lack/loss of response $\mathrm{AE}$ reporting in later years which had a larger proportion of GLM- and GLM-IV-patients.
Also, despite its respectable size, BioTRAC had limited ability to detect rare AEs unlike large national registries, such as the UK's BSRBR, Sweden's ARTIS, Germany's RABBIT, Denmark's DANBIO, Spain's BIOBADASER and the US's CORRONA [10]. Indeed, most Canadian

Table 6 Adverse events of interest (preferred terms; malignancies in $\geq 2$ patients, serious infections in $\geq 2$ patients, Herpes Zoster, tuberculosis and opportunistic infections)

\begin{tabular}{|c|c|c|c|c|c|c|c|c|c|c|c|c|}
\hline & \multicolumn{4}{|c|}{$\operatorname{IFX}(\boldsymbol{N}=890)$} & \multicolumn{4}{|c|}{$\operatorname{GLM}(\boldsymbol{N}=530)$} & \multicolumn{4}{|c|}{ GLM-IV $(\boldsymbol{N}=157)$} \\
\hline & $\begin{array}{l}\mathrm{N} \text { of } \\
\text { Events }\end{array}$ & $\begin{array}{l}\mathrm{N} \text { of } \\
\text { Patients }\end{array}$ & $\begin{array}{l}\% \text { of } \\
\text { Patients }\end{array}$ & $\begin{array}{l}\text { Rate/100 } \\
\text { Pt-Yrs }\end{array}$ & $\begin{array}{l}\mathrm{N} \text { of } \\
\text { Events }\end{array}$ & $\begin{array}{l}\mathrm{N} \text { of } \\
\text { Patients }\end{array}$ & $\begin{array}{l}\% \text { of } \\
\text { Patients }\end{array}$ & $\begin{array}{l}\text { Rate/100 } \\
\text { Pt-Yrs }\end{array}$ & $\begin{array}{l}\mathrm{N} \text { of } \\
\text { Events }\end{array}$ & $\begin{array}{l}\mathrm{N} \text { of } \\
\text { Patients }\end{array}$ & $\begin{array}{l}\% \text { of } \\
\text { Patients }\end{array}$ & $\begin{array}{l}\text { Rate/100 } \\
\text { Pt-Yrs }\end{array}$ \\
\hline \multicolumn{13}{|l|}{ Malignancies } \\
\hline Acrochordon & 2 & 2 & $0.2 \%$ & 0.07 & 0 & 0 & 0 & 0 & 0 & 0 & 0 & 0 \\
\hline $\begin{array}{l}\text { Basal cell } \\
\text { carcinoma }\end{array}$ & 2 & 1 & $0.1 \%$ & 0.07 & 2 & 2 & $0.4 \%$ & 0.19 & 0 & 0 & 0 & 0 \\
\hline Breast cancer & 5 & 5 & $0.6 \%$ & 0.17 & 2 & 2 & $0.4 \%$ & 0.19 & 0 & 0 & 0 & 0 \\
\hline Leukemia & 0 & 0 & 0 & 0 & 3 & 2 & $0.4 \%$ & 0.28 & 0 & 0 & 0 & 0 \\
\hline $\begin{array}{l}\text { Lung } \\
\text { adenocarcinoma }\end{array}$ & 1 & 1 & $0.1 \%$ & 0.03 & 2 & 2 & $0.4 \%$ & 0.19 & 0 & 0 & 0 & 0 \\
\hline Lymphoma & 2 & 2 & $0.2 \%$ & 0.07 & 0 & 0 & 0 & 0 & 0 & 0 & 0 & 0 \\
\hline $\begin{array}{l}\text { Non-Hodgkin's } \\
\text { lymphoma }\end{array}$ & 2 & 2 & $0.2 \%$ & 0.07 & 0 & 0 & 0 & 0 & 0 & 0 & 0 & 0 \\
\hline $\begin{array}{l}\text { Renal cell } \\
\text { carcinoma }\end{array}$ & 2 & 2 & $0.2 \%$ & 0.07 & 0 & 0 & 0 & 0 & 0 & 0 & 0 & 0 \\
\hline $\begin{array}{l}\text { Squamous cell } \\
\text { carcinoma }\end{array}$ & 4 & 4 & $0.4 \%$ & 0.14 & 0 & 0 & 0 & 0 & 0 & 0 & 0 & 0 \\
\hline Uterine cancer & 2 & 2 & $0.2 \%$ & 0.07 & 1 & 1 & $0.2 \%$ & 0.09 & 0 & 0 & 0 & 0 \\
\hline \multicolumn{13}{|l|}{ Serious infections } \\
\hline Arthritis bacterial & 4 & 3 & $0.3 \%$ & 0.14 & 2 & 2 & $0.4 \%$ & 0.19 & 0 & 0 & 0 & 0 \\
\hline Cellulitis & 6 & 6 & $0.7 \%$ & 0.21 & 1 & 1 & $0.2 \%$ & 0.09 & 0 & 0 & 0 & 0 \\
\hline Pneumonia & 23 & 19 & $2.1 \%$ & 0.80 & 5 & 5 & $0.9 \%$ & 0.46 & 1 & 1 & $0.6 \%$ & 0.39 \\
\hline Pyelonephritis & 1 & 1 & $0.1 \%$ & 0.03 & 3 & 2 & $0.4 \%$ & 0.28 & 0 & 0 & 0 & 0 \\
\hline Sepsis & 3 & 3 & $0.1 \%$ & 0.03 & 0 & 0 & 0 & 0 & 0 & 0 & 0 & 0 \\
\hline Urosepsis & 2 & 2 & $0.2 \%$ & 0.07 & 1 & 1 & $0.2 \%$ & 0.09 & 0 & 0 & 0 & 0 \\
\hline \multicolumn{13}{|c|}{ Herpes Zoster, tuberculosis and opportunistic infections } \\
\hline Herpes Zoster & 19 & 19 & $2.1 \%$ & 0.66 & 14 & 13 & $2.5 \%$ & 1.30 & 1 & 1 & $0.6 \%$ & 0.39 \\
\hline $\begin{array}{l}\text { Tuberculosis } \\
\text { (disseminated) }\end{array}$ & 1 & 1 & $0.1 \%$ & 0.03 & 0 & 0 & 0 & 0 & 0 & 0 & 0 & 0 \\
\hline Candidiasis & 4 & 4 & $0.4 \%$ & 0.14 & 0 & 0 & 0 & 0 & 0 & 0 & 0 & 0 \\
\hline Histoplasmosis & 1 & 1 & $0.1 \%$ & 0.03 & 0 & 0 & 0 & 0 & 0 & 0 & 0 & 0 \\
\hline Onychomycosis & 2 & 2 & $0.2 \%$ & 0.07 & 0 & 0 & 0 & 0 & 0 & 0 & 0 & 0 \\
\hline
\end{tabular}


multi-center registries, such as BioTRAC, $\mathrm{CATCH}$ [25], OBRI [26] and RHUMADATA [27], are smaller in scope but still provide significant insights on the treatment of RA at a regional level. CATCH, OBRI and RHUMADATA have the advantage over BioTRAC of being disease registries enrolling RA patients taking any therapy (biologic and non-biologic DMARDs). $\mathrm{CATCH}$ is an early RA disease registry enrolling newly diagnosed RA patients while OBRI and RHUMADATA enrolls RA patients from academic and community centers but are restricted to the provinces of Ontario and Quebec, respectively $[26,27]$. Despite those differences in design, it has been possible to increase power and answer specific scientific questions by combining patient data from multiple registries [28].

One key strength of BioTRAC is that it included an extensive evaluation of clinical disease parameters, most of which were not collected elsewhere, especially in the early years [10]. Due to its long-term duration, BioTRAC offered a unique opportunity to evaluate the real-world effectiveness and safety of three anti-TNF agents in a community Canadian setting, while assessing regional variations due to differences in patient profiles, practice patterns and local reimbursement policies impacting access to care over 16 years. Although there has been extensive real-world evidence generated on the early antiTNF agents such as IFX or etanercept, very little efficacy data has been published with other anti-TNF agents such as GLM, and most of those only presented persistence data $[15,29-31]$. One exception, however, is the GO NICE prospective non-interventional trial in Germany for inflammatory arthritis patients treated with GLM [15, 32]. This 2-year trial also found significant clinical effectiveness among RA patients [15], as well as improvements in patient-reported health status, physical function, and fatigue levels [32].

\section{Conclusion}

In conclusion, this real-world study identified differences in baseline characteristics between Canadian RA patients treated with an anti-TNF over time and between agents. The study also revealed potential biases when selecting a given therapy which may impact the proportion of patients achieving a target-specific outcome. Finally, treatment with IFX, GLM and GLM-IV significantly reduced disease activity and improved functionality in a similar fashion and all agents were safe and well- tolerated.

\section{Supplementary information}

Supplementary information accompanies this paper at https://doi.org/10. 1186/s41927-020-00145-4.

Additional file 1: Supplemental Table 1. Discontinuations and reasons for discontinuations with IFX between 2010 and 2014 and with
GLM. Supplemental Figure 1. Time to Discontinuation Due to Lack/ Loss of Efficacy or Disease Progression between 2010 and 2014 with IFX vs. GLM.

\section{Abbreviations}

AE: Adverse event; AM: Morning; bDMARD: Biologic DMARD; BioTRAC: Biologic Treatment Registry Across Canada; CRP: C-Reactive protein; DMARD: Disease-modifying antirheumatic drug; ESR: Erythrocyte sedimentation rate; GLM: Golimumab; GLM-IV: Golimumab intravenous; IFX: Infliximab; MTX: Methotrexate; HAQ-DI: Health Assessment Questionnaire Disease Index; MACE: Major adverse cardiovascular event; MDGA: Physician global assessment of disease activity; PtGA: Patient global assessment of disease activity; RA: Rheumatoid arthritis; RCT: Randomized-controlled trial; SAE: Serious adverse event; SD: Standard deviation; SJC28: Swollen joint count based on 28 joints; TJC28: Tender joint count based on 28 joints

\section{Acknowledgements}

This study is dedicated to the memory of William G. Bensen MD, who was BioTRAC's primary investigator from its inception in 2002 until his premature passing on March 15th, 2017. The authors are indebted to the BioTRAC investigators, nurses, study coordinators and to the individuals who were involved in its design, management, data generation and dissemination: Vincent Letourneau, John Leombruno, Hayssam Khalil, Chad Mitchell, SophieElise Michaud, Frank Hack, Nader Khabboul, Heidi Imhoff, Susan Otawa, May Shawi, Kathy Tkaczyk, Karina Maslova, Brendan Osborne, Odalis Asin-Milan, Meagan Rachich, John S. Sampalis, Eliofotisti Psaradellis, Nadia Longo, Julie Vaillancourt, Angela Karellis, Saliha Boumaza, Patricia Bandeira, Karen Landers, Clara Fehrmann, Julie Dinniwell, Debra Mitchell and Sandra Sitar. We also wish to thank all the people living with rheumatoid arthritis who shared their time in the study to help us better understand the impact of their disease.

\section{Authors' contributions}

$P R, P B, E K, C T, D C, B H, A C, R F, W O$ and JK were involved in recruitment. ER was involved in biostatistical analysis. FN, AJL and ER were involved in the study design and FN wrote the manuscript. All authors were involved in data analysis, reviewed and edited the manuscript and approved the final version.

\section{Funding}

This study was financed in its entirety and managed by Schering-Plough (from 2002 to 2010; study design and data collection), Merck (from 2010 to 2012; study amendment design and data collection) and Janssen Inc. (from 2012-present; study amendment design, data collection, analysis, interpretation and writing).

\section{Availability of data and materials}

Janssen has an agreement with the Yale Open Data Access (YODA) Project to serve as the independent review panel for evaluation of requests for CSRS and participant level data from investigators and physicians for scientific research that will advance medical knowledge and public health. For more information on this process or to make a request, please go to https://yoda. yale.edu/.

\section{Ethics approval and consent to participate}

Prior to enrollment, patients were required to provide written informed consent to participate. Ethics approval was obtained from a central Research Ethics Board (IRB Service, Ontario, Canada) for private practices, and from respective Research Ethics Boards for institutional sites. The study was conducted in accordance with the Declaration of Helsinki.

\section{Consent for publication}

Not applicable.

\section{Competing interests}

Proton Rahman has received consulting fees for Abbott, AbbVie, Amgen, BMS, Celgene, Janssen, Novartis, Pfizer and Roche; and received research grant from Janssen.

Philip Baer has received consultant fees from AbbVie, Amgen, Janssen, Lilly, Novartis, Boehringer Ingelheim, Pfizer Inc., Sanofi-Genzyme and Merck and speaker's fees from Amgen, Janssen, Abbvie, Pfizer Inc. and Lilly. Ed Keystone received funding for research from AbbVie, Amgen, Gilead Sciences, Lilly 
Pharmaceuticals, Merck, Pfizer Pharmaceuticals, PuraPharm, Sanofi; consulting agreements/advisory board membership from AbbVie, Amgen, AstraZeneca Pharma, Bristol-Myers Squibb Company, Celltrion, Myriad Autoimmune, F. Hoffmann-La Roche Inc., Genentech Inc., Gilead, Janssen Inc., Lilly Pharmaceuticals, Merck, Pfizer Pharmaceuticals, Sandoz, Sanofi-Genzyme, Samsung Bioepsis; speaker honoraria from Amgen, AbbVie, Bristol-Myers Squibb, Hoffmann-La Roche Inc., Janssen Inc., Merck, Pfizer Pharmaceuticals, Sanofi Genzyme and UCB. Denis Choquette has received consulting and speaking fees from Bristol-Myers Squibb, Abbvie, Amgen, Celgene, Genentech, Amgen, Pfzer, Roche and Novartis. Boulos Haraoui received advisory boards/consulting, and/or received research grants from AbbVie, Amgen, BMS, Celgene, Janssen, Eli Lilly, Merck, Novartis, UCB Pharma and Pfizer. Andrew Chow received advisory boards/consulting, and/or received research grants: AbbVie, Amgen, AstraZeneca, BMS, Celgene, Eli Lilly, Genzyme, GSK, Janssen, Merck, Novartis, Pfizer, Roche, Sanofi Aventis and UCB Pharma. Rafat Faraawi received consultant and speaker fees from Janssen Inc. Wojciech Olszynski received speaker/consultant fees for Amgen, Merck, Novartis, and Warner Chilcott. JPB: research grants, consulting fees, or speakers' bureau fees from Abbott, Amgen, Bristol Myers Squibb, Eli Lilly, Merck, Novartis, Pfizer, Roche, Sanofi-Aventis, Servier, Takeda, and Warner Chilcott. John Kelsall reports personal fees from Abbott, AstraZeneca, BMS, Merck-Schering, Lilly, Pfizer, Wyeth, Roche, Takeda and UCB. Allen Lehman and Francois Nantel are employees of Janssen Inc. and are JNJ stockholders.

\section{Author details}

${ }^{1}$ Memorial University, St. John's, NL, Canada. ${ }^{2}$ Scarborough, Canada. ${ }^{3}$ University of Toronto, Toronto, ON, Canada. ${ }^{4}$ Institut de Rhumatologie de Montréal, Montreal, QC, Canada. ${ }^{5}$ Newmarket, Canada. ${ }^{6}$ Mississauga, ON, Canada. ${ }^{7}$ McMaster University, Hamilton, ON, Canada. ${ }^{8}$ University of Saskatchewan, Saskatoon, SK, Canada. ${ }^{9}$ Providence Health, Vancouver, BC, Canada. ${ }^{10}$ JSS Medical Research, Montreal, QC, Canada. ${ }^{11}$ Janssen Inc., 19 Green Belt Dr., Toronto, ON M3C 1N9, Canada.

\section{Received: 30 January 2020 Accepted: 3 June 2020}

Published online: 19 September 2020

\section{References}

1. Smolen JS, Aletaha D, McInnes IB. Rheumatoid arthritis. Lancet. 2016; 388(10055):2023-38.

2. Bykerk VP, Akhavan P, Hazlewood GS, Schieir O, Dooley A, Haraoui B, et al. Canadian Rheumatology Association recommendations for pharmacological management of rheumatoid arthritis with traditional and biologic diseasemodifying antirheumatic drugs. J Rheumatol. 2012;39(8):1559-82.

3. Burmester GR, Pope JE. Novel treatment strategies in rheumatoid arthritis. Lancet. 2017;389(10086):2338-48.

4. Kilcher G, Hummel N, Didden EM, Egger M, Reichenbach S, GetReal Work P. Rheumatoid arthritis patients treated in trial and real world settings: comparison of randomized trials with registries. Rheumatology. 2018;57(2): 354-69

5. Mariette X, Gottenberg JE, Ravaud P, Combe B. Registries in rheumatoid arthritis and autoimmune diseases: data from the French registries. Rheumatology. 2011;50(1):222-9.

6. Thorne C, Bensen WG, Choquette D, Chow A, Khraishi M, Atkins CJ, et al. Effectiveness and safety of infliximab in rheumatoid arthritis: analysis from a Canadian multicenter prospective observational registry. Arthritis Care Res. 2014;66(8):1142-51.

7. Silverman ED. Canadian Rheumatology Association Meeting Fairmont The Queen Elizabeth Montreal, Quebec, Canada February - March 2, 2019. J Rheumatol. 2019. https://doi.org/10.3899/jrheum.190333.

8. Abstracts, 21st PANLAR Meeting. J Clin Rheumatol. 2019;25:S1-S96.

9. Annual European Congress of Rheumatology EULAR 2019. Ann Rheum Dis. 2019;78(Supplement 2):1-2270.

10. Ruderman EM. Overview of safety of non-biologic and biologic DMARDs. Rheumatology. 2012;51(Suppl 6):vi37-43.

11. Atzeni F, Sarzi-Puttini P, Botsios C, Carletto A, Cipriani P, Favalli EG, et al. Long-term anti-TNF therapy and the risk of serious infections in a cohort of patients with rheumatoid arthritis: comparison of adalimumab, etanercept and infliximab in the GISEA registry. Autoimmun Rev. 2012;12(2):225-9.

12. Pappas DA, Kremer JM, Griffith J, Reed G, Salim B, Karki C, et al. Long-term effectiveness of adalimumab in patients with rheumatoid arthritis: an observational analysis from the Corrona rheumatoid arthritis registry. Rheumatol Ther. 2017:4(2):375-89.

13. Harrold LR, Litman HJ, Saunders KC, Dandreo KJ, Gershenson B, Greenberg $J \mathrm{D}$, et al. One-year risk of serious infection in patients treated with certolizumab pegol as compared with other TNF inhibitors in a real-world setting: data from a national U.S. rheumatoid arthritis registry. Arthritis Res Ther. 2018;20(1):2

14. Iannone F, Semeraro A, Carlino G, Santo L, Bucci R, Quarta L, et al. Effectiveness of certolizumab-pegol in rheumatoid arthritis, spondyloarthritis, and psoriatic arthritis based on the BIOPURE registry: can early response predict late outcomes? Clin Drug Invest. 2019;39(6): 565-75.

15. Kruger K, Burmester GR, Wassenberg S, Bohl-Buhler M, Thomas MH. Effectiveness and safety of golimumab in patients with rheumatoid arthritis, psoriatic arthritis and ankylosing spondylitis under real-life clinical conditions: non-interventional GO-NICE study in Germany. BMJ Open. 2018; 8(6):e021082.

16. Keystone EC, Genovese MC, Klareskog L, Hsia EC, Hall ST, Miranda PC, et al. Golimumab, a human antibody to tumour necrosis factor \{alpha\} given by monthly subcutaneous injections, in active rheumatoid arthritis despite methotrexate therapy: the GO-FORWARD study. Ann Rheum Dis. 2009;68(6): 789-96.

17. Maini R, St Clair EW, Breedveld F, Furst D, Kalden J, Weisman M, et al. Infliximab (chimeric anti-tumour necrosis factor alpha monoclonal antibody) versus placebo in rheumatoid arthritis patients receiving concomitant methotrexate: a randomised phase III trial. ATTRACT Study Group. Lancet. 1999;354(9194):1932-9.

18. Choquette D, Faraawi R, Chow A, Rodrigues J, Bensen WJ, Nantel F. Incidence and management of infusion reactions to infliximab in a prospective real-world community registry. J Rheumatol. 2015;42(7):1105-11.

19. Singh JA, Cameron C, Noorbaloochi S, Cullis T, Tucker M, Christensen R, et al. Risk of serious infection in biological treatment of patients with rheumatoid arthritis: a systematic review and meta-analysis. Lancet. 2015; 386(9990):258-65

20. Galloway JB, Hyrich KL, Mercer LK, Dixon WG, Fu B, Ustianowski AP, et al. Anti-TNF therapy is associated with an increased risk of serious infections in patients with rheumatoid arthritis especially in the first 6 months of treatment: updated results from the British Society for Rheumatology Biologics Register with special emphasis on risks in the elderly. Rheumatology. 2011;50(1):124-31.

21. Sakai R, Komano Y, Tanaka M, Nanki T, Koike R, Nagasawa H, et al. Timedependent increased risk for serious infection from continuous use of tumor necrosis factor antagonists over three years in patients with rheumatoid arthritis. Arthritis Care Res. 2012;64(8):1125-34.

22. Au K, Reed G, Curtis JR, Kremer JM, Greenberg JD, Strand V, et al. High disease activity is associated with an increased risk of infection in patients with rheumatoid arthritis. Ann Rheum Dis. 2011;70(5):785-91.

23. Favalli EG, Desiati F, Atzeni F, Sarzi-Puttini P, Caporali R, Pallavicini FB, et al. Serious infections during anti-TNFalpha treatment in rheumatoid arthritis patients. Autoimmun Rev. 2009;8(3):266-73.

24. Askling J, Fored CM, Brandt L, Baecklund E, Bertilsson L, Feltelius N, et al. Time-dependent increase in risk of hospitalisation with infection among Swedish RA patients treated with TNF antagonists. Ann Rheum Dis. 2007; 66(10):1339-44

25. Bykerk VP, Jamal S, Boire G, Hitchon CA, Haraoui B, Pope JE, et al. The Canadian Early Arthritis Cohort (CATCH): patients with new-onset synovitis meeting the 2010 ACR/EULAR classification criteria but not the 1987 ACR classification criteria present with less severe disease activity. J Rheumatol. 2012;39(11):2071-80.

26. Pope JE, Rampakakis E, Movahedi M, Cesta A, Li X, Couto S, et al. Treatment patterns in rheumatoid arthritis after discontinuation of methotrexate: data from the Ontario Best Practices Research Initiative (OBRI). Clin Exp Rheumatol. 2018;36(2):215-22.

27. Choquette D, Bessette L, Alemao E, Haraoui B, Postema R, Raynauld JP, et al Persistence rates of abatacept and TNF inhibitors used as first or second biologic DMARDs in the treatment of rheumatoid arthritis: 9 years of experience from the Rhumadata(R) clinical database and registry. Arthritis Res Ther. 2019;21(1):138.

28. Keystone E, Rampakakis E, Movahedi M, Cesta A, Stutz M, Sampalis JS, et al. Towards defining primary and secondary non-response in rheumatoid arthritis patients treated with anti-TNFs: results from the BioTRAC and OBRI 
registries. J Rheumatol. 2020;47(4):510-17. https://doi.org/10.3899/jrheum. 190102.

29. Calip GS, Adimadhyam S, Xing S, Rincon JC, Lee WJ, Anguiano RH. Medication adherence and persistence over time with self-administered TNF-alpha inhibitors among young adult, middle-aged, and older patients with rheumatologic conditions. Semin Arthritis Rheum. 2017;47(2):157-64.

30. Dalen J, Svedbom A, Black CM, Lyu R, Ding Q, Sajjan S, et al. Treatment persistence among patients with immune-mediated rheumatic disease newly treated with subcutaneous TNF-alpha inhibitors and costs associated with non-persistence. Rheumatol Int. 2016;36(7):987-95.

31. Takacs P, Lathia U, Shin J, Nantel F. Persistence to subcutaneous biological agents in Hungarian patients treated for inflammatory arthritis. Patient Prefer Adherence. 2019;13:157-63.

32. Kruger K, Burmester GR, Wassenberg S, Bohl-Buhler M, Thomas MH. Patientreported outcomes with golimumab in patients with rheumatoid arthritis, psoriatic arthritis, and ankylosing spondylitis: non-interventional study GONICE in Germany. Rheumatol Int. 2019;39(1):131-40.

\section{Publisher's Note}

Springer Nature remains neutral with regard to jurisdictional claims in published maps and institutional affiliations.

Ready to submit your research? Choose BMC and benefit from:

- fast, convenient online submission

- thorough peer review by experienced researchers in your field

- rapid publication on acceptance

- support for research data, including large and complex data types

- gold Open Access which fosters wider collaboration and increased citations

- maximum visibility for your research: over $100 \mathrm{M}$ website views per year

At BMC, research is always in progress.

Learn more biomedcentral.com/submissions 